\title{
PROSES PENGOLAHAN IKAN TERI (Stolephorus sp.)DAN PEMANFAATAN \\ LIMBAHNYA SEBAGAI BAHAN BAKU PAKAN IKAN \\ DALAM MENDUKUNG KONSEP ZERO WASTE
}

\section{PRODUCTS PROCESSING OF ANCHOVIES (Stolephorus sp.) AND IT'S WASTE POTENTIALAS RAW MATERIAL FOR FEED IN IMPLEMENTING ZERO WASTE CONCEPT}

\author{
Mahrus Ali* ${ }^{11}$, Eko Efendi $^{1)}$, dan Nuning Mahmudah Noor ${ }^{2)}$ \\ ${ }^{1)}$ Jurusan Perikanan dan Ilmu Kelautan, Fakultas Pertanian, Univesitas Lampung \\ Jl. Prof. Soemantri Brojonegoro No. 1, Gedongmeneng, Bandar Lampung \\ ${ }^{2)}$ Program Studi Budidaya Perikanan, Politeknik Negeri Lampung \\ Jl. Soekarno-Hatta No. 10, Bandar Lampung
}

\begin{abstract}
Abstrak
Pulau Pasaran dikenal sebagai penghasil ikan teri (Stolephorussp.) di provinsi Lampung dengan jumlah produksi mencapai 57,6 ton setiap bulannya. Hal ini menjadikan Pulau Pasaran sebagai sentra penghasil ikan di provinsi Lampung. Upaya pengolahan yang dilakukan oleh masyarakat menghasilkan berbagai bentuk produk seperti ikan teri kering, teri kemasan vakum dan produk diversifikasi untuk makanan ringan serta pengolahn limbah sebagai bahan baku pakan (feed) untuk ikan nila dan lele. Upaya pengolahan ini disamping dapat meningkatkan nilai tambah (value added) dari ikan teri juga dapat menerapkan konsep zero waste dalam proses pengolahan ikan teri, sehingga pendapatan masyarakat lebih optimal.
\end{abstract}

Kata kunci: ikan teri, tepung ikan, limbah, pakan, lele, nila

\begin{abstract}
Pasaran island is well known as a center of anchovy producer in the province of Lampung, Indonesia. The total of catched fish is to 57.6 tons per month so Pasaran island was classified as fisheries cluster producing anchovies in the province of Lampung. The processing units from fishing, curing, drying, processing to marketing steps was conducted by small and medium enterprises (SME's) from local community. They producedvarious products such as dried anchovies, packaged vacum anchovies, snack, and raw material for feed of nila and catfish from anchovies waste. Theseintegrated processing system not only increasing the added values of anchovies in Pasaran islandbut also applying zero waste concept in the processing anchovies. Thus impacted on increasing SME's and local community incomes.
\end{abstract}

Keywords: anchovy, waste, fish meal, feed, catfish, tilapia

\section{Pendahuluan}

Pakan memegang peranan penting dalam kegiatan budidaya ikan. Penyediaan pakan selama budidaya membutuhkan hingga 60-70\% dari biaya operasional (Sahwan, 2003).Hal ini terjadi karena bahan baku pembuatan pakan khususnya tepung ikan masih dipenuhi dengan cara diimpor dengan harga mencapai Rp. 15.000,- perkilogram. *email korespondensi: pakmahrusali@gmail.com
Sehingga diperlukan alternatif bahan baku pakan berbasis sumberdaya lokal.

Pulau Pasaran dikenal sebagai penghasil ikan teri sejak tahun 1963dan menjadi sentra pengolahan ikan teri di provinsi Lampung dengan produksi bulanan mencapai 57,6 ton (DKP Kota Bandar Lampung, 2014).Usaha pengolahan ikan teri merupakan usaha rakyat dengan teknologi pengolahan yang masih sederhana yaitu memadukan 
proses penggaraman (salting) dan pengeringan (sun drying). Meskipun begitu, usaha pengolahan di Pulau Pasaran masih konsisten dan bertahan hingga 2 generasi dengan produk utama berupa ikan teri asin (dried anchovy).

$$
\text { Melimpahnya tangkapan dan }
$$

beragamnya olahan ikan teri di Pulau Pasaran juga berimbas pada tingginya limbah pengolahan yaitu limbah perebusan dan limbah kepala ikan teri (jengki) yang dibuang ke selokan atau laut. Menurut Ali dkk. (2015), limbah kepala teri jengki mencapai $15 \%$, sedangkan limbah sisa perebusan ikan teri berkisar 5\% dari total produksi. Limbah perebusan terdiri dari rontokan ikan selama pemanasan berbentuk limbah padat (sludge), juga terdapat limbah sortasi terhadap potongan atau bagian tubuh ikan yang tidak bisa dimanfaatkan (debris). Keberadaan limbah ini dapat mencemari lingkungan karena menimbulkan bau dan menjadi sumber penyakit.

Tulisan ini bertujuan mengkaji potensi pemanfaatan limbah ikan teri dari Pulau Pasaran, Lampung menjadi tepung sebagai bahan baku pakan ikan (feed) hingga menghasilkan teknologi pengolahan ikan tanpa limbah (zero waste). Adanya upaya ini diharapkan dapat meningkatkan nilai tambah (value added) dari usaha pengolahan ikan teri dan menjadi alternatif usaha bagi masyarakat.

\section{Metodologi Penelitian}

\begin{abstract}
Metode penelitian menggunakan gabungan dari observasi, interwiewdan rancangan penelitian (RAL). Metode observasi dan interwiew dilakukan untuk mengidentifikasi proses pengolahan ikan teri dan produk diversifikasinya pada pengolah ikan dan tokoh masyarakat di Pulau Pasaran. Observasi bertujuan mendapatkan informasi mengenai situasi dan kondisi riil, sedangkan interview dilakukan untuk mendapatkan informasi yang lebih rinci (Arikunto, 2002). Metode rancangan acak lengkap dilakukan untuk membandingkan kualitas dan aplikasi pakan dari limbah ikan teri dan pakan ikan komersil.
\end{abstract}

Sampel limbah ikan teri yang akan dijadikan sebagai bahan baku pakan ikan diperoleh dari pengolah ikan teri di Pulau Pasaran (05027'57.698”S, 105 ${ }^{0} 15^{\prime} 37.299$ ”'E). Proses pembuatan pakan dimulai dari pengeringan, penggilingan menggunakan hummer mill dan pengayakan hingga menjadi tepung. Selanjutnya formulasi pakan (Tabel 1), dilanjutkan dengan pengadukan, pencetakan, pengeringan dan pengujian kualitas pakan.

Tabel 1. Formulasi pakan (mengacu pada SNI, 2006)

\begin{tabular}{lccc}
\hline \multirow{2}{*}{ Bahan Pakan $(\mathrm{g})$} & \multicolumn{3}{c}{ Formulasi pakan } \\
\cline { 2 - 4 } & $\mathrm{A}$ & $\mathrm{B}$ & $\mathrm{C}$ \\
\hline Tepung ikan impor & 300 & 0 & 0 \\
Tepung kepala teri & 0 & 300 & 0 \\
Tepung perebusan teri & 0 & 0 & 300 \\
Tepung kedelai & 230 & 230 & 230 \\
Tepung jagung & 150 & 150 & 150 \\
Tepung terigu & 45 & 45 & 45 \\
Minyak ikan & 22,5 & 22,5 & 22,5 \\
Minyak jagung & 15 & 15 & 15 \\
Premix & 7,5 & 7,5 & 7,5 \\
\hline Jumlah & 750 & 750 & 750 \\
\hline
\end{tabular}

Analisis kualitas pakan dilakukan melalui uji proksimat yang meliputi: uji kadar protein (kjedhall), lemak (shoxlet), air (thermogravimetry), dan kadar abu (muffle) (Sudarmadji dkk,1996). Analisis ini juga dilakukan pada produk dan limbah ikan teri.

Selanjutnya uji efektivitas pakan dilakukan pada juvenile ikan nila merah (Oreochromis niloticus) dan lele dumbo (Clarias batracus) menggunakan wadah akuarium $60 \times 40 \times 40 \mathrm{~cm}^{3}$. Frekuensi pemberian pakan sebanyak tiga kali sehari dengan feeding rate 5\% dari bobot tubuh ikan.

Pengamatan yang dilakukan meliputi: nilai pertumbuhan (Effendie, 1997), feed convertion ratio (FCR) (Zonneveld dkk., 1991), dan retensi protein (Takeuchi, 1988) dari pakan berbahan limbah ikan teri dibandingkan kontrol pakan berbahan tepung ikan impor. Data yang diperoleh kemudian diolah menggunakan minitab v14.0 serta dilaporkan secara deskriptif.

\section{Hasil}

\section{Pengolahan Ikan Teri di Pulau Pasaran}

Hasil wawancara dengan pengolah ikan teri di Pulau Pasaran menunjukkan bahwa proses penangkapan ikan teri dilakukan dengan menggunakan payang (seine net) atau bagan (lift net). Tangkapan nelayan sangat fluktuatif tergantung pada musim, kondisi alam dan evolusi bulan. Produksi paling tinggi terjadi pada bulan April sampai September, 
terutama ketika bulan gelap karena ikan berenang ke permukaan dan mudah ditangkap. Di mana hasil tangkapan utamanya terdiri dari jenis teri nasi (Stolephorus baganensis), teri nilon (Stolephorus heterolobus), dan teri jengki (Stolephorus insularis).

Usaha pengolahan ikan teri di Pulau Pasaran meliputi: penangkapan, pengeringan ikan, usaha diversifikasi menjadi produk snack dan usaha ikan teri kemasan vakum dengan merk Teri Siger (Gambar 1). Proses pengolahan dilakukan sejak di atas kapal dimana pengolah ikan teri di Pulau Pasaran membeli ikan segar di tengah laut dari nelayan penangkap ikan menggunakan bagan.

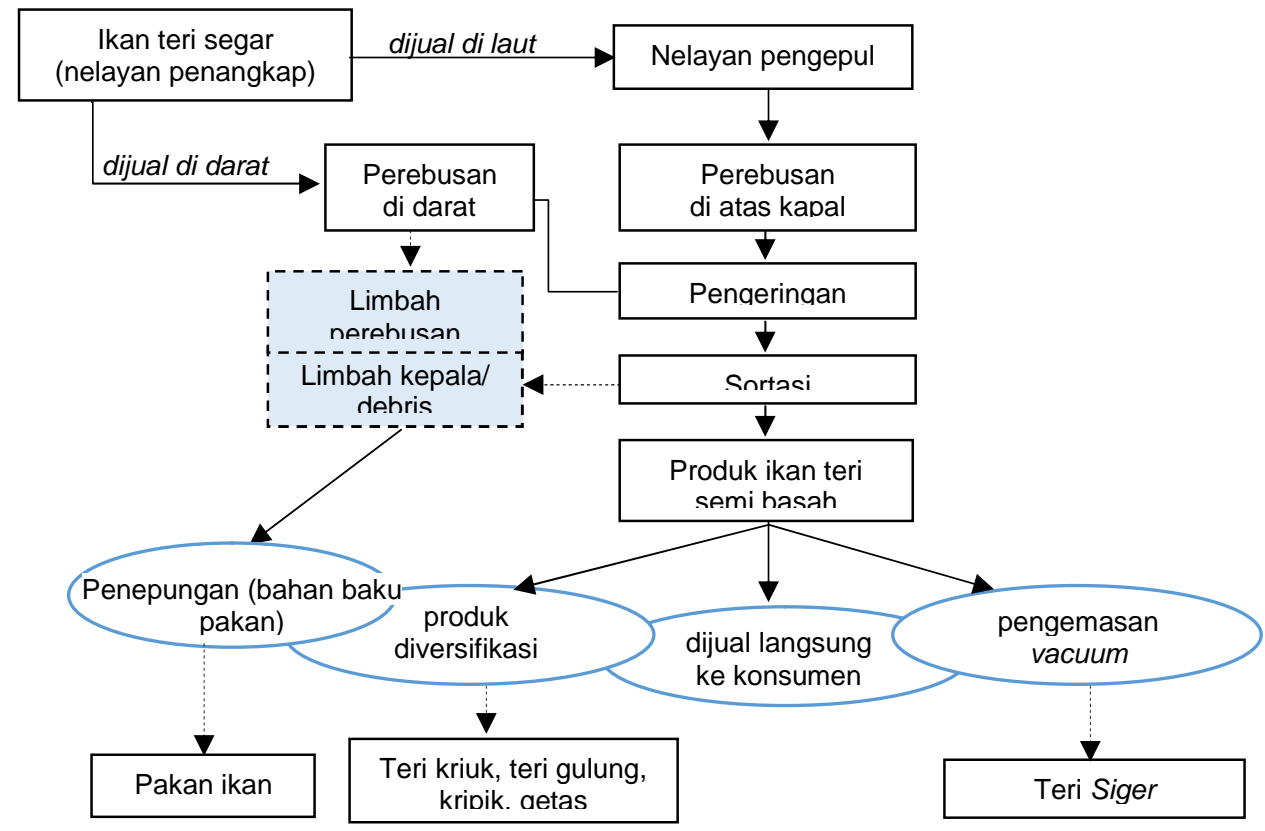

Gambar 1. Alur proses dan penerapan zero waste pada pengolahan ikan teri di Pulau Pasaran, Lampung

Perahu yang digunakan telah dimodifikasi agar bisa langsung merebus ikan teri di atas kapal dengan menggunakan kompor berbahan bakar gas (LPG). Hal ini dilakukan untuk menghindari penurunan kualitas dan kebusukan ikan karena jarak dari bagan (fishing ground) ke Pulau Pasaran relatif jauh, disamping itu juga untuk mempertahankan kualitas produk agar tetap baik. Di samping itu juga terdapat pengolah ikan teri yang melakukan proses perebusan di darat yang biasanya dilakukan oleh nelayan payang atau pengusaha kecil yang tidak memiliki perahu untuk menyongsong bahan baku ikan dari nelayan bagan di tengah laut.

\section{Limbah Ikan Teri}

Tingginya produksi ikan teri di Pulau Pasaranjuga menyebabkan limbah pengolahanberupa limbah kepala ikan, terutama pada jenis teri jengki yang harus dibuang karena berasa pahit. Selanjutnya limbah serpihan atau patahan ikan (debris) selama sortasi, limbah perebusan (blanching) dan limbah ikan rucah yang ikut tertangkap (by catch) (Gambar 1).

Sebelum diolah menjadi pakan, limbah ikan teri terlebih dahulu dijadikan tepung yang diawali dengan proses pengeringan, penggilingan dan pengayakan untuk mendapatkan tekstur tepung yang seragam. Kualitas tepung ikan (Tabel 2) yang dihasilkan menunjukkan kadar protein hingga mencapai 44,43\% dan 26,18\% untuk limbah kepala dan perebusan (Tabel 2).

\section{Kualitas Pakan Berbasis Limbah Ikan Teri}

Nilai proksimat pakan yang dihasilkan menunjukkan beberapa kualtias yang kurang sesuai dengan SNI (2006), terutama kadar lemak dan kadar abu produk. Analisis varian menunjukkan nilai kadar lemak dan air 
memiliki peredaan yang signifikan pada masing-masing perlakuan (Tabel 3).Meskipun demikian, analisis organoleptik pakan (data tidak ditampilkan) menunjukkan karakteristik pakan dari bahan baku yang berbeda relatif tidak berbeda nyata dengan pakan berbahan dasar tepung ikan impor.

Tabel 2. Nilai proksimat produk ikan teri dan limbahnya

\begin{tabular}{lccc}
\hline \multirow{2}{*}{ Nilai gizi (\%) } & Ikan teri & \multicolumn{2}{c}{ Tepung limbah } \\
\cline { 3 - 4 } & (semi kering) & kepala teri & sisa rebusan \\
\hline Air & $42,25 \pm 0,7$ & $11,27 \pm 1,2$ & $8,13 \pm 1,0$ \\
Protein & $40,86 \pm 1,3$ & $44,43 \pm 1,6$ & $26,18 \pm 0,4$ \\
Lemak & $1,81 \pm 1,7$ & $6,35 \pm 0,5$ & $5,39 \pm 0,8$ \\
Abu & $6,62 \pm 0,9$ & $24,25 \pm 1,4$ & $50,00 \pm 1,3$ \\
Karbohidrat & $9,06 \pm 1,1$ & $13,68 \pm 1,0$ & $10,30 \pm 0,8$ \\
\hline
\end{tabular}

Tabel 3. Nilai proksimat pakan dari limbah teri

\begin{tabular}{lcccc}
\hline \multirow{2}{*}{ Nilai $(\%)$} & \multicolumn{3}{c}{ Pakan } & SNI \\
\cline { 2 - 4 } & Komersil & kepala teri & sisa rebusan & $(2006)$ \\
\hline Air & $12.21 \pm 0,5^{\mathrm{b}}$ & $10,4 \pm 1,1^{\mathrm{ab}}$ & $6,60 \pm 0,4^{\mathrm{a}}$ & maks. 12 \\
Protein & $29.71 \pm 0,7$ & $29,67 \pm 1,6$ & $28,08 \pm 1,7$ & min. 30 \\
Lemak & $10.74 \pm 1,4^{\mathrm{a}}$ & $14,65 \pm 1.2^{\mathrm{b}}$ & $18,34 \pm 2,4^{\mathrm{c}}$ & maks. 5 \\
Abu & $17.75 \pm 0.9$ & $15,27 \pm 0,8$ & $15,38 \pm 1,7$ & 13 \\
Karbohidrat & $29.57 \pm 0,6$ & $30,0 \pm 1,1$ & $31,6 \pm 1,4$ & 6 \\
\hline
\end{tabular}

\section{Uji Pakan pada Ikan Lele dan Nila Merah}

Uji in vivo pakan dilakukan pada ikan

lelestrain dumbo dan ikan nila merah menunjukkan nilai pertumbuhan tertinggi pada bibit lele dumbo (Gambar 2) dengan menggunakan pakan dari tepung limbah kepala teri sebesar 16,25 gram setelah dipelihara selama 50 hari, nilai ini lebih baik dari pada menggunakan tepung ikan komersil. Sementara terendah terdapat pada pakan berbahan dasar sisa rebusan teri (10,49 gram).
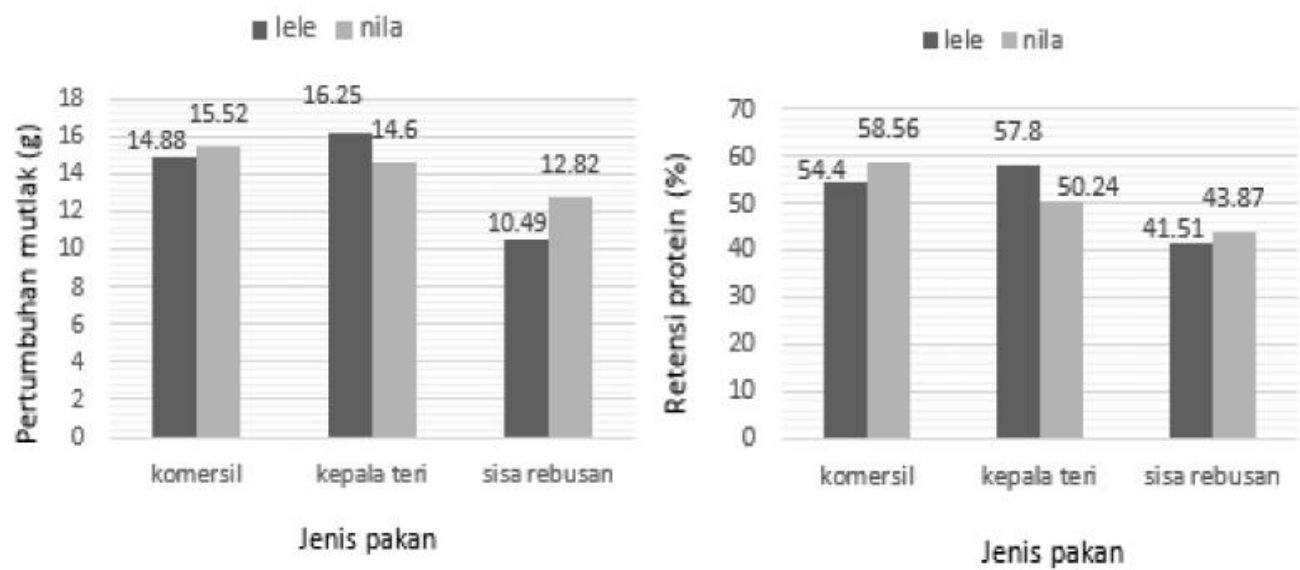

Gambar 2. Pertumbuhan ikan dan retensi protein pakan

Retensi protein tertinggi terdapat pada pada nila merah dengan pakan tepung komersil $(58,56 \%)$, sedangkan terendah pada lele dumbo dengan pakan tepung sisa perebusan teri $(41,51 \%)$. Nilai retensi protein dari pakan berbahan tepung ikan komersil, kepala teri dan pakan dari sisa rebusan secara berturut-turut memiliki nilai konversi pakan yang semakin menurun (Gambar 2).

Nilai feed convertion ratio (FCR) perlakuan berksiar 1, 25 hingga 1,48. Nilai FCR terbaik terdapat pada pakan dengan 
bahan baku tepung ikan komersil diikuti oleh tepung kepala teri dan tepung sisa perebusan teri (Gambar 3).

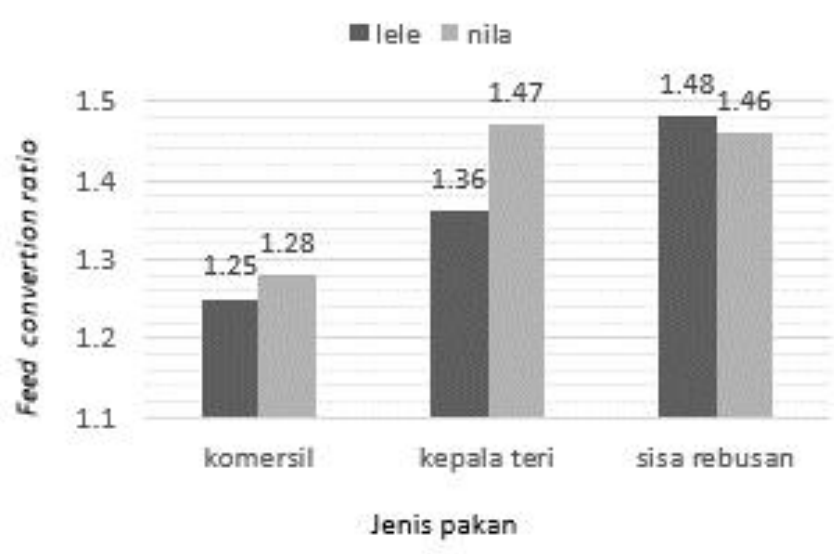

Gambar 3. Feed convertion ratio pada ikan lele dan nila merah

\section{Pembahasan}

Pulau Pasaran terletak di Kecamatan Teluk Betung Barat dan berjarak $5 \mathrm{~km}$ dari kota Bandar Lampung. Pulau seluas 12 hektar ini dihuni oleh sebanyak 224 kepala keluarga dan menjadi sentra pengolahan ikan teri di provinsi Lampung. Didukung oleh luasnya fishing groundyang tersebar mulai dariTeluk Lampung hingga Selat Sunda yang terintegrasi dengan proses pengolahan di Pulau Pasaran menjadikan produksi bulanan dapat mencapai 57,6 ton (DKP Kota Bandar Lampung, 2014).

Pengolahan ikan teri di Pulau Pasaran telah menghasilkan berbagai produk olahan, tidak hanya terbatas pada ikan teri asin kering (dried anchovy) melainkan juga terdapat produk diversifikasi berupa produk makanan ringan (snack), seperti: teri kriuk, getas teri, keripik teri dan teri gulung (Gambar 1). Produk diversifikasi ini diproduksi oleh kelompok ibu-ibu nelayan guna meningkatkan nilai tambah dari teri dan menjadi solusi penanganan ketika produksi melimpah (Subur, 2016). Pengolahan lainnya adalah ikan teri kemasan vakum dengan merek Teri Siger yang dikembangkan untuk menjadi produk ikan teri khas Lampung(Ali, 2015).

Tingginya produksi ikan teri di Pulau Pasaran juga menyebabkan adanya limbah pengolahan yang berupa limbah kepala ikan, terutama pada jenis teri jengki yang harus dibuang karena berasa pahityang tidak disukai konsumen. Selanjutnya limbah serpihan atau patahan ikan (debris) selama sortasi, limbah perebusan (blanching). Limbah perebusan terdiri dari rontokan ikan selama pemanasan berbentuk limbah padat (sludge). Sejauh ini limbah kepala ikan teri belum dimanfaatkan maksimal, hanya diambil oleh pembudidaya itik dan ayam di sekitar Bandar Lampung dengan harga Rp. 1.000,-per kilogram dan limbah perebusan dibuang karena tidak laku dijual.

Limbah lainnya berupa ikan yang bukan tangkapan utama (by catch) atau unwanted catches yang menurut Davies dkk. (2009) bisa mencapai $40 \%$ dari total tangkapan. By catch terkadang langsung dibuang ke laut dalam keadaan sudah mati sehingga mencemari lingkungan (Condie dkk., 2014), namun terkadang juga masih terikut pada proses pengolahan terutama jika ukuran spesies sama seperti ikan teri dan ikan rucah, seperti halnya pada pegolahan ikan teri di Pulau Pasaran.

Limbah kepala ikan teri jengki di Pulau Pasaran sebesar $15 \%$ dari ikan teri jengki (Ali dkk., 2015). Hal ini menunjukkan bahwa jika produksi bulanan ikan teri jenis jengki mencapai 14,4 ton perbulan, yakni sebesar $25 \%$ dari total produksi bulanan (eDKP Kota Bandar Lampung, 2014), maka limbah kepala ini dapat mencapai hingga 2,2 ton perbulan. Sementara limbah sisa perebusan berkisar 5\% dari total produksi ikan atau setara 9 ton perbulan.

Di satu sisi limbah ikan masih kaya akan nutrisi seperti asam amino, asam lemak, yodium dan lainnya, sehingga masih potensial untuk dimanfaatkan dari pada dibuang (Gormaz and Fry, 2014). Menurut Visvanathan (2007), alternatif pengolahan limbah ikan diantaranya sebagai bahan baku bidang farmasi, gelatin dari kulit dan tulang, tepung dan minyak ikan, silase, kompos, pupuk, ataupun pakan.

Pemanfaatan hasil samping atau limbah ikan sebisa mungkin digunakan untuk produk pangan sebab disamping nilai ekonomisnya akan lebih tinggi juga masih mengandung nutrisi yang tinggi (Mekpiroon dkk., 2016). Namun demikian beberapa limbah pengolahan tidak bisa dijadikan sebagai bahan pangan karena alasan estetika dan keamanan (food safety), sehingga alternatif lain dengan menjadikannya sebagai bahan baku pakan ataupun untuk bidang pertanian. 
Pengolahan limbah ikan berbasis pakan biasanya dijadikan dalam bentuk silase ataupun tepung ikan (Ristic dkk, 2002). Sekalipun nutrisi silase lebih tinggi dan pembuatannya lebih sederhana, namun faktor bau yang menyengat dan lokasi pengolahan silase berpotensi menjadi masalah di kemudian sehingga limbah ikan di Pulau Pasaran lebih disarankan untuk dijadikan tepung ikan. Kelemahan lain silase adalah kerena produknya berbentuk cair atau pasta sehingga memerlukan biaya tambahan dalam proses pengeringannya.

Tepung ikan merupakan sumber protein terbaik bagi ikan, selain kaya asam amino esensial, juga mengandung carotenoid dan profilnya juga cocok untuk kebutuhan nutrisi ikan (Guillaume dkk., 2001). Disamping lemaknya terkandung asam lemak tak jenuh ganda (PUFA) baik berupa omega 3 ataupun omega 6 yang penting dalam meningkatkan sistem imun dan mengurangi stres pada ikan, juga memiliki fosfolipid, vitamin larut lemak, dan steroid yang diperlukan selama pertumbuhan (Miles and Capman, 2015).

Pembuatan tepung ikan berbasis limbah ikan teri dilakukan melaluiproses pengeringan, penggilingan dan pengayakan untuk mendapatkan tekstur tepung yang seragam. Kualitas tepung yang dihasilkan (Tabel 2) menunjukkan tingginya nilai kadar protein hingga mencapai $44,43 \%$ dan $26,18 \%$ untuk limbah kepala dan limbah perebusan.

Zahari and Alimon (2004), menjelaskan bahwa bahan baku pakan ikan harus memiliki beberapa kriteria antara lain: kandungan proteinnya berkisar 30-60\%, ketersediaan melimpah, harga bahan alternatif tersebut harus lebih murah dibandingkan tepung ikan impor. Sehingga berdasarkan kriteria tersebut maka limbah pengolahan ikan teri dapat dijadikan sebagai bahan subtitusi tepung ikan impor dalam pakan (feed).

Pakan yang mempunyai nutrisi cukup dapat mempercepat laju pertumbuhan ikan karena menghasilkan energi yang cukup untuk mengganti sel tubuh yang rusak. Pakan ikan kualitas prima mengandung protein $32-45 \%$ (Miles and Capman, 2015). Lovell (1989), kebutuhan protein ikan dalam ransumnya berkisar antara $25-50 \%$, sementara ikan lele sekitar 25-36\% dan pada ikan nila sebesar 20$35 \%$ tergantung usia dan jenis kelamin (Meyer and Pena, 2001).
Hasil uji pakan menunjukkan bahwa bibit nila merah memiliki pertumbuhan yang tertinggi pada pemberian pakan dengan bahan baku tepung ikan komersil dikuti berbahan kepala teri dan sisa rebusan teri. Yolanda (2013), mendapatkan berat nila kisaran 9,015,8 gram, sehingga penggunaan tepung kepala ikan teri menghasilkan pertumbuhan yang lebih baik. Data ini sesuai dengan Ali dkk. (2014), yang meneliti pemberian pakan berbahan tepug kepala ikan lele strain Masamo.

Rendahnya nilai pertumbuhan pada lele dumbo dan nila merah pada pakan sisa rebusan dikarenakan protein tepung rendah (Tabel 2) yang diakibatkan oleh adanya pemasakan limbah perebusan secara terusmenerus. Hal ini akan menurunkan fungsional dari protein disamping akan mengalami denaturasi. Menurut Gusrina (2008), bahwa idealnya kebutuhan protein ikan lele adalah 25-36\%, atau 26\% pada spesies Channel catfish (Halver and Hardy, 2002).

Nilai retensi protein yang merupakan jumlah protein pakan yang diserap dan terkonversi menjadi protein dalam tubuh ikan untuk membangun, memperbaiki sel rusak, serta metabolisme (Dani dkk., 2005). Tinggi rendahnya nilai retensi protein dipengaruhi oleh bahan pakan dan kemampuan ikan dalam mencerna protein serta kebutuhan ikan akan asam amino tersebut (Webster and Lim, 2002).

Penggunaan tepung ikan rucah dengan kadar protein sebesar $44 \%$ menghasilkan nilai retensi protein pada nila merah sebesar 44,31\%, (Selpiana dkk., 2013), sedangkan retensi protein terendah pada penelitian ini sebesar 30,09\%, sehingga bahan baku dalam penelitian ini relatif lebih baik dibandingkan dengan menggunakan ikan rucah. Namun masih lebih rendah dari Penelitian Ali dkk. (2015), menunjukkan nilai retensi protein nila sebesar $67,8 \%$,

Feed convertion ratio (FCR) menunjukkan efektifitas pemberian pakan pada ikan budidaya. Tingkat efisiensi pakan yang terbaik akan dicapai pada nilai konversi pakan terendah (Handayani, 2006). Semakin tinggi FCR maka pakan yang dibutuhkan untuk pemeliharaan semakin besar sehingga tidak efisien dalam penggunaan pakan yang tidak sebanding dengan penambahan bobot ikan.

Nilai FCR terbaik terdapat pada pakan dengan bahan baku tepung ikan komersil 
diikuti oleh tepung kepala teri dan tepung sisa perebusan teri. Hal ini terjadi karena limbah ikan teri mengalami proses pemasakan berulang-ulang sehingga fungsional protein berkurang, sementara tepung ikan impor menggunakan teknologi pressing yang tidak merusak protein. FCR ikan lele strain Masamo yang diberi pakan berbahan limbah teri berkisar 1,17 (Ali dkk., 2014) sedangkan ikan nila sebesar 1,01 (Ali dkk., 2015).

Analisis kelayakan usaha (data tidak ditampilkan), menunjukkan biaya produksi pembuatan pakan berbahan tepung ikan komersil sebesar Rp.12.135,- perkilogram, dengan pendapatan Rp. 23.800,- dan keuntungan Rp.11.665. Sementara jika tepung ikan disubstitusi dengan limbah ikan teri membutuhkan biaya produksi sebesar Rp.10.335,- perkilogram dan menghasilkan pendapatan sebesar Rp. 25.200,- serta keuntungan sebesar Rp.14.865.-

Hasil ini menunjukkan bahwa substitusi tepung ikan impor dengan limbah pengolahan teri cukup efektif karena biaya produksi lebih murah dan meningkatkan nilai tambah limbah pengolahan ikan teri. Disamping itu mengurangi dampak negatif pembuangan limbah ikan di selokan atau di pantai seperti bau tidak sedap maupun timbulnya penyakit akibat sanitasi yang kurang baik.

\section{Kesimpulan}

Ikan teri di Pulau Pasaran Lampung telah diolah menjadi produk ikan teri kering, produk diversifikasi dan produk kemas vakum. Pemanfaatan limbah kepala, tulang, sisa daging dan sisa perebusan ini merupakan upaya pengolahan ikan tanpa limbah (zero waste concept) yang penting dalam meningkatkan pendapatan nelayan Pulau Pasaran dan menjaga lingkungan tetap sehat.

\section{Ucapan Terima Kasih}

Ucapan terima kasih sampaikan kepada Direktorat Jenderal Pendidikan Tinggi Kementerian Riset Teknologi dan Pendidikan Tinggi bekerja sama dengan Lembaga Penelitian dan Pengabdian Universitas Lampung yang telah mendanai kegiatan ini melalui program Hi Link Tahun 2016.

\section{Daftar Pustaka}

Ali, M., A.N. Darjatun dan S. Hudaidah. (2014). Pemanfaatan kepala ikan teri jengki (Stelophorus insularis) sebagai bahan substitusi tepung ikan untuk bahan baku ikan lele Masamo (Clariassp). Prosiding Seminar Nasional BKS PTN Barat. Bandar Lampung. 19-21 Agustus 2014: 436-441.

Ali, M., L. Santoso and D. Fransisca. (2015). The substitution of fish meal by using anchovies head waste to increase the growth of tilapia (Oreochromis sp.). Maspari, 7 (1): 63-70

Ali, M. (2015). Potensi wisata bahari Pulau Pasaran Bandar Lampung. Prosiding Seminar Nasional Swasembada Pangan Politeknik Negeri Lampung, 29 April 2015: 568-575.

Arikunto, S. (2002). Prosedur penelitian: suatu pendekatan praktek. Jakarta:Rineka Cipta.

BI [Bank Indonesia]. (2012). Percepatan pertumbuhan sektor riil melalui kegiatan pengembangan klaster UMKM. Bandar Lampung: Bank Indonesia Lampung.

Buckle, K.A. R.A. Edwards, G.H. Fleet. dan M. Wooton. (1987). Ilmu pangan. Jakarta: UI Press.

Capone, R., A Bennett, P. Debs, C.A. Bucatariu, H. El Bilali, J.Smolak, W.T.K. Lee, F. Bottalico, Y. Diei-Ouadi, J. Toppe. (2016). Food losses and waste: global overview from a Mediteranean perspective. Mediterra. CIHEAM and FAO. Paris: 192p.

Condie, H.M., A. Grant and T.L. Catchpole. (2014). Incentivising selective fishing under a policy to ban siscards: Lessons from European and global fisheries, Marine Policy, 45: 287-292

Dani, N.P., A. Budiharjo, S. Listyawati. (2005). Komposisi pakan buatan untuk meningkatkan pertumbuhan dan kandungan protein ikan tawes (Puntius javanicus Blkr). Biosmart. 7 (2): 83-90.

Davies, R.W.D, S.J. Cripps, A. Nickson and G. Porter. (2009), Defining and estimating global marine fisheries bycatch, Marine Policy, 33: 661-672.

DKP [Dinas Kelautan dan Perikanan Kota Bandar Lampung]. (2014). Profil sentra pengolah hasil perikanan ikan Teri Siger Pulau Pasaran. Lampung: DKP Kota Bandar Lampung. 
Effendie, M. I. (1997). Biologi perikanan. Yogyakarta: Yayasan Pustaka Nusatama.

Gormaz, J.G. and J.P. Fry. (2014). Public health perspectives on aquaculture. Current Environmental Health Reports. 1 (3): 227-238.

Guillaume, J., S. Kaushik., P. Bergot and R. Métailler. (2001). Nutrition and feeding of fish and crustaceans. Chichester:Praxis Publishing Ltd.

Gusrina. (2008). Budidaya ikan. Jakarta: Departemen Pendidikan Nasional.

Halver, J.E. and R.W. Hardy. (2002). Fish nutrition. $3^{\text {rd }}$. California USA: Academic Press Inc.

Handayani, H. (2006). Pemanfaatan tepung azolla sebagai penyusun pakan ikan terhadap pertumbuhan dan daya cerna ikan nila merah (Oreochromis sp.). Jurnal aquaculture. 1 (2): 162-170.

Lovell, T. (1989). Nutrition of fish. New York: Van Nostrand reinhold.

Mekpiroon, A. W Lerdrattranataywee, W Jutidamrongphan. 2016. Prespective of waste utilization in seafood industry. Proceedings of 26th IASTEM International Conference: $11-15 p$

Meyer, D.E.P. and P. Pena. (2001). Ammonia excretion rates and protein adequacy in diets for tilapia Oreochromis sp. World Aquaculture Society. 61-70

Miles, R.D. and F.A. Chapman. (2015). The benefits of fish meal in aquaculture diets. Department of Fisheries and Aquatic Sciences, IFAS, University of Florida: 1$6 \mathrm{p}$.

Ristic, M.D. S.S. Filipovic, M.L.J. Sakac. (2002). Liquid protein feedstuffs from freshwater fish byproducts as a component of animal feed. Romanian Biotechnological Letters, 7: 729-736.

Sahwan, M.F. (2003). Pakan ikan dan udang: formulasi, pembuatan, analisis ekonomi. Jakarta: Penebar Swadaya.

Selpiana, L. Santoso dan B. Putri (2013). Kajian tingkat kecernaan pakan buatan yang berbasis tepung ikan rucah pada ikan nila merah (Oreochromis niloticus).
Jurnal Rekayasa dan Teknologi Budidaya Perairan. 1(2): 101-108.

SNI [Standar Nasional Indonesia]. (2006). Pakan buatan untuk ikan lele dumbo (Clarias gariepinus) pada budidaya intensif. SNI 01-4087-2006. Jakarta: Badan Standarisasi Nasional.

Subur. (2016). Pengolahan ikan teri di Pulau Pasaran. Komunikasi pribadi Tanggal 10 Juli 2016

Sudarmadji, S., Haryono, B., Suhardi, (1996). Analisa bahan makanan dan pertanian. Yogyakarta: Penerbit Liberty.

Takeuchi, T. (1988). Laboratory workchemical evaluation of dietary nutrients in Watanabe, T. (Ed). Fish nutrition and mariculture JICA textbook. The General Aquaculture Course. Kanagawa International Fisheries Training Centre: JICA.

Visvanathan, C. (2007). Seafood processing: Term project in industrial waste abatement and Management. Retrived from

http://www.fpeac.org/seafood/Industrial WasteAbatement-Seafood.pdf.

Webster, C.D. and C.E. Lim. (2002). Nutrient requirements and feeding of finfish for aquaculture. New York: CABI Publishing.

Yolanda, S. (2013). Substitusi tepung ikan dengan tepung ikan rucah terhadap pertumbuhan ikan nila gesit (Oreochromis niloticus).Jurnal Rekayasa dan Teknologi Budidaya Perairan. 2 (1), Februari 2013.

Zahari, W. and A.R. Alimon. (2004). Use of palm kernel cake and oil palm by products in compound feed. Palm Oil Development, 40:5-9.

Zonneveld, N., Huisman, E.A. dan Boon, J.H. (1991). Prinsip-prinsip budidaya ikan. Jakarta: Gramedia Pustaka Utama. 